\title{
Margareta Mikkelsen, 4 November 1923-28 June 2004
}

\author{
European Journal of Human Genetics (2005) 13, $271-272$. doi:10.1038/sj.ejhg.5201338 \\ Published online 1 December 2004
}

Margareta Mikkelsen died on 28 June 2004, and with her death Denmark and Europe lost one of the best and most influential scientists in the field of clinical genetics. Margareta was born in Germany in 1923. After commencing her medical studies in Germany during the war, she completed them in Denmark (having married a Dane) and hence moving to Denmark in 1947. She graduated from Copenhagen University in 1955. She did not have an easy life, either personally or professionally, and her success was a reflection of her sterling qualities as a human being, clinician and scientist.

In 1959 she obtained a position in the University Institute of Medical Genetics in Copenhagen. The head of the institute was Professor Tage Kemp, from whom she received training in medical genetics and, together with Anders Froland, started to build a cytogenetics laboratory. From the very beginning, the main focus of her research interest was Down syndrome, as interest that she maintained for her whole life. Her early work was primarily on familial forms of Down syndrome, both those due to translocations and those resulting from repeated trisomy in the same family. From the earliest days she visited the families herself, and still continued this many years after her official retirement. Margareta's empathy and ability to deal with people at all levels was legendary. From her special interest in the familial occurrence of Down syndrome, the subject of her thesis that was awarded in 1967 (DMSci), she branched out into a general study of the syndrome with a special focus on aetiology and genetic counselling. This research interest was carried out both with her colleagues in Denmark and on an international scale, and she made major contributions to our understanding of the meiotic errors underlying nondisjunction in the gametes that give rise to individuals with an additional chromosome 21 .

In 1969 Margareta's university post came to an end. When she applied for the newly created post as head of the department, she was told that she could only stay in the department as a laboratory technician! This blow was the spur that made her decide to find another position. Fortunately, she had developed an important collaboration with the head of the National Service for the Mentally Retarded, who recruited her for a position as head of the department at the newly created John F Kennedy Institute. It was here that she started the internationally renowned chromosome laboratory. The chromosome laboratory performed cytogenetic diagnosis for a wide segment of the Danish population both in Copenhagen and beyond. From this service aspect, a strong research programme evolved and early on served as a training facility for clinical geneticists. Thus, in Denmark, cytogenetics, clinical genetics and research in human genetics with special reference to mental retardation all stemmed directly from Margareta's foresight, guidance and hugely beneficial influence.

Margareta's interest in familial Down syndrome led directly to her desire to introduce prenatal diagnosis. She did this in 1970 when she and Professor Aage Therkelsen undertook the first prenatal diagnosis by amniocentesis in Denmark. From then on she played a prominent role in the promulgation of prenatal diagnosis both nationally and internationally, and this led to her growing interest in the ethical aspects of prenatal diagnosis and other aspects of genetics. She published a number of authoritative papers and reports on ethical matters and figured prominently on both national and international committees.

It was inevitable that anyone with an interest in the causes of mental retardation would be drawn into work with the Fragile X Syndrome. Margareta visited Hawaii on two occasions, where she became enthused with work on the Fragile $\mathrm{X}$ Syndrome and forged a very productive working relationship with Drs Stephanie Sherman and Terry Hassold, young postdocs in the groups of Professors Newton Morton and the undersigned (Patricia Jacobs). Together, they undertook collaborative work on the aetiology of Down syndrome, a collaboration that lasted long past her official retirement. As one of Margareta's students, one of us wrote her thesis on the Fragile $\mathrm{X}$ Syndrome, and Fragile $\mathrm{X}$ still forms a major research focus of the JFK Institute. Margareta developed a great love for Hawaii because she found that swimming in its tropical waters greatly alleviated her very painful symptoms of rheumatoid arthritis, from which she suffered all her adult life. Furthermore, the symptoms remained at bay for many years after her return to Denmark.

Margareta had extensive European collaborations. From the very beginning, she was an influential member of the 
European Society of Human Genetics. She was a Board member and became President in 1993. She chaired the successful 24th meeting of the Society in 1992 in Elsinore.

It is a testament to Margareta's talent as a mentor for a whole generation of Danish clinical geneticists that all her students have made such a large contribution in human genetics. To name but a few, Karen Brondum-Nielsen became director of the JFK Institute on Margareta's retirement, Niels Tommerup is head of the Department of Medical Genetics at the University of Copenhagen and Nina Horn is head of the biochemical research group at the JFK Institute. However, Margareta did not restrict her attention to Danish genetics. She also encouraged young researchers from Eastern Europe and became an honorary member of both the Hungarian and the Yugoslavian Medical Genetics Society. Only a month before her death she also became an honorary member of the German Genetical Society.

Margareta will long be remembered for her contribution to virtually all aspects of human genetics, which resulted in over 170 publications in international journals. However for those of us who had the privilege of knowing her, she will best be remembered as a remarkable person with a great generosity towards friends, colleagues and employees. Parties at her home in Northern Copenhagen overlooking the Oresund were often international and always enjoyable, with not only first class food and wine but more importantly much laughter, some science and good stories.

Patricia A Jacobs ${ }^{1}$ and Karen Brondum-Nielsen ${ }^{2}$

${ }^{1}$ Wessex Regional Genetics Laboratory, Salisbury, England;

${ }^{2}$ The John F Kennedy Institute, Glostrup, Denmark 